Article

\title{
Limits of Land Capitalization and Its Economic Effects: Evidence from China
}

\author{
Jian Cheng (D), Jiangmeng Zhao, Daolin Zhu * and Hui Zhang \\ College of Land Science and Technology, China Agricultural University, Beijing 100193, China; \\ chengjian@cau.edu.cn (J.C.); S20193030522@cau.edu.cn (J.Z.); S20183030372@cau.edu.cn (H.Z.) \\ * Correspondence: dlzhu@cau.edu.cn
}

Citation: Cheng, J.; Zhao, J.; Zhu, D.; Zhang, H. Limits of Land Capitalization and Its Economic Effects: Evidence from China. Land 2021, 10, 1346. https://doi.org/ 10.3390/land10121346

Academic Editor: Richard C. Feiock

Received: 24 November 2021

Accepted: 3 December 2021

Published: 6 December 2021

Publisher's Note: MDPI stays neutral with regard to jurisdictional claims in published maps and institutional affiliations.

Copyright: (c) 2021 by the authors. Licensee MDPI, Basel, Switzerland. This article is an open access article distributed under the terms and conditions of the Creative Commons Attribution (CC BY) license (https:// creativecommons.org/licenses/by/ $4.0 /)$.

\begin{abstract}
Academic debates over the advantages and disadvantages of land capitalization are ongoing in China, but the fundamental issues behind the debate have not been adequately explored. We suggest that the core issue in land capitalization is the degree of capitalization. This study first theoretically deduced the existence of land capitalization limits; then, we used panel data from 35 key cities to conduct an empirical test, and finally we analyzed the current risk of excessive land capitalization in China. The results indicated that the mutual restriction of multiple land attributes determined the limits of land capitalization. Therefore, land capitalization has been categorized into two types-moderate and excessive - which produce different economic effects. The degree of land capitalization and real economic growth showed a significant inverted-U relationship, and the turning point appeared when the land capital value reached 2.5 times the land factor value. According to this threshold, we can infer that many key cities have been overcapitalized, which may lead to an economic recession and affect the growth prospects of China's economy. Further analysis indicated that excessive land capitalization could be related to the unique Chinese style of decentralization. These conclusions have important policy implications for the reform of land marketization in countries undergoing economic transition. The goal of land reform is to allow the market mechanism to play a major role in land resource allocation, but the excessive capitalization of land must be prevented.
\end{abstract}

Keywords: land economics; land capitalization; real economic growth; limit; land system reform; China

\section{Introduction}

Since the industrial revolution, capital has been an important driving force leading economic growth [1]. Understanding how to convert solid, hidden, and even invisible economic resources into liquid capital to promote capital accumulation and improve economic efficiency is important for the development of late-developing countries [2]. In this context, land has been constructed as an asset by society, which is at the center of capital creation and has been widely discussed around the world [3-7]. Land capitalization is understood as investment in land productivity; the transformation of land into commodities through property rights transactions; and the emergence of land as a financial asset [3,8-11]. Relying on land capitalization to finance economic development has a long history [12,13]. De Soto's proposal to revitalize rigid land assets through formalization has been adopted by many countries and development agencies [4]. Since then, the number and scale of formalized property rights projects in developing countries and transition countries have multiplied [14]. It is said with relish that land capitalization plays a key role in supporting fiscal revenue and infrastructure construction [15]. In Warsaw, Poland, land capital income exceeds municipal borrowing by 20 percent. In Cairo, Egypt, the capital income of 3100 hectares of desert land is equivalent to 117 times the total urban property tax collections in the country. Land capital income is also considerable in many countries such as China, India, Turkey, and South Africa [12]. 
In recent years, however, the process of unconstrained land capitalization has been widely questioned worldwide. Land has become a lucrative investment place, and profits are generated mainly through financial means rather than production means $[16,17]$. Speculation and development of land and real estate in many cities are intensifying, and real estate prices have risen sharply, exceeding the affordability of residents [16,18]. As economic development becomes increasingly speculative, it is easy to trigger a real estate crisis, resulting in a sharp depreciation of assets and possibly a broader economic collapse $[3,19]$. As an outcome of land capitalization through investment, commercialization, and financialization, land ownership in many countries has become highly unequal [11]. In addition, various forms of land grabs have occurred, and the urban poor have been expelled and displaced $[7,20,21]$.

This study focuses on land capitalization in China. China is considered to have adopted a fanatical land capitalization strategy, which has suffered as much damage as it has provided benefits, which has caused a significant change in the attitude of academia and government departments toward land capitalization.

Before China's economic transition, the government had prohibited land transactions, and land was allocated free of charge. Land was considered neither a commodity nor an asset [22]. However, various subsequent land system reforms activated land assets and enabled China to form a unique model of capital creation, which resulted in an explosion of capital and long-term high economic growth [8]. Empirical research has shown that for every $1 \%$ increase in land capitalization (measured by land conveyance fees), fixed capital formation will increase by $0.2157 \%$, and gross domestic product (GDP) will increase by $0.1950 \%$ [1]. Therefore, it is often suggested that the activation of previously rigid land assets was the original driving force of China's urban economic development and that the land-centric development model was one of the secrets of China's rapid economic growth [2,23].

In recent years, however, China has experienced an economic downturn and its developmental model has faced increasing scrutiny. Liu [24] argued that although land capitalization helped China achieve an economic leap, it also gave rise to the country's current economic transformation dilemma. Issues of concern in China today include excessive occupation of arable land, food security, ecological problems, and sustainable agricultural and rural development [25]. In China's cities, real estate bubbles, high living costs, and land waste have become severe [25]. Meanwhile, the income gap between regions and between urban and rural residents has also widened rapidly [26]. Zhang and Liu [27] found that the rapid increase in urban land prices inhibited industrial development and led to premature deindustrialization. Another major problem is the high level of local government debt and its potential systemic financial risks, which could have disastrous consequences [28]. According to statistics from the Ministry of Natural Resources, the area and amount of land mortgages rose from 166,600 hectares and 1,810.7 billion yuan in 2008 to 490,800 hectares and 11,330 billion yuan in 2015 [29]. These loans are invested primarily in some low-yield projects such as infrastructure construction, and the proceeds from these projects are difficult to repay debts. Finally, scholars have also noted that the land-centric development model has a significant impact on carbon emissions [30].

These studies have provided evidence regarding both the advantages and disadvantages of land capitalization. Few studies [29,31], however, have linked the positive and negative economic effects of land capitalization theoretically or empirically. Instead, previous studies have focused on the impact of land capitalization on the overall national economy without giving much consideration to the impact on the real economy. Because land capitalization belongs to the scope of the virtual economy, clarifying how it affects the real economy is key to understanding its economic effects. This study, therefore, empirically investigated the nonlinear effects of different degrees of land capitalization on the real economy and further explored why China's land capitalization is overdeveloped.

This study makes the following contributions. First, unlike the general view, this study considers the "degree" of land capitalization and divides it into moderate and 
excessive, which helps to explain its contradictory economic effect. Second, a quantitative measurement method for land capitalization degree is proposed. This method can help stimulate quantitative research on land capitalization as well as the further development of methodologies in the field. At the same time, this method considers the factors of land speculation, which is helpful to study the impact of land capitalization on the real economy.

The rest of this article is organized as follows. Section 2 reviews the relevant literature and makes a theoretical analysis. Section 3 proposes a new measurement method for land capitalization and introduces the model and the data. Section 4 presents the results and analyzes the risk of excessive land capitalization, and Section 5 examines the institutional reasons for the continuous increase in land capitalization. Section 6 discusses the results of the study. Section 7 concludes with findings and policy implications.

\section{Theoretical Analysis}

First, we review the relevant literature. Then, we explain why land capitalization has a limit by analyzing the natural attributes and functions of land. Finally, based on practice in China, we analyze the mechanism of the effect of different degrees of land capitalization on the real economy.

\subsection{Literature Review}

From the investment in land productivity to land commercialization and the emergence of land as a financial asset, land capitalization has been deepening in history [3,8-11]. "Turning land into capital" has become the theme of active new land liberalization. De Soto [4] believes that poor residents in the non-Western world have failed to benefit from capitalism because they are unable to produce capital despite holding large amounts of assets. The key to converting assets into capital is to establish a property right and property information system, which is applied nationwide and "clearly visible" to outsiders. His arguments have been supported by various political factions and development institutions, and widely popularized. Feder and Nishio [32] also believe that the formalization of individual property rights is beneficial to the land market, because information costs can be saved under the background of information asymmetry. Most of these studies are based on the property rights theory and the concept of strong privatization, underpinned by the idea that the efficiency of land market can be improved through clear property right distribution and formalization. Although the potential of using land as an asset is huge, it also comes with many types of risks. In recent years, more and more scholars have begun to reflect on promoting land capitalization through the formalization of complete private property rights, especially nongovernmental organizations engaged in human rights work, because this path has become a shortcut to benefiting the minority through the accumulation of wealth while depriving the majority, which has resulted in livelihood difficulties of vulnerable groups [33]. In addition, the formalization of property rights has increased the inequality of land ownership in many countries, which has not only failed to promote, but has also hindered economic development [33].

In the new stage, the discussion of international land capitalization has fallen under the background of financialization and neoliberalism. Land capitalization is regarded as the key process and foundation of global financialization and neoliberalism. An increasing amount of political economy literature has been published on the treatment of urban and rural land as financial assets, and its influence is increasing [6]. According to these studies, land increasingly tends to be regarded as a tradable financial asset, and its exchange value takes precedence over use value. The buyers and sellers of land are actually trading on future value [3,34]. As Gunnoe [35] claims, we are witnessing "an unprecedented integration between finance capital and landownership." In The Limits to Capital, Harvey [3] believes that what we are increasingly seeing is that the sale of land is not based on the use of land by the buyer and seller, but rather is based more on its exchange value. Harvey [3] has described this conversion from use to exchange value as "a growing trend to treat land as a pure financial asset." Financialized land markets are more speculative than markets 
based on more stable use values, often leading to land price bubbles. The potential systemic risks brought about by the land asset bubble have been proved in the case of Japan. In the late 1980s, the value of land skyrocketed, and bank loans to land and real estate developers increased, followed by the collapse of the value of land assets, leading to a long-term economic recession in Japan [36].

The state, like other actors, increasingly regards its own land as a financial asset [6]. The World Bank reported that more than half of the land in 19\% of the cities was publicly owned; in another 19\% of the cities, more than a quarter of the urban land was publicly owned. This ratio is highest in Asia, Eastern Europe, Central Europe, the Middle East and Africa, and the ratio is lower in Latin America and North America [37]. These public land assets are the most valuable assets of subnational governments. These lands are used for direct sale or mortgage loans, which is the most common way land is financed. But at the same time, the capitalization of public land also brings many types of threats: (1) selling public land at a price lower than the actual value wastes public land; (2) the rapid depletion of land resources means that there will be no land for use in the future; (3) unhealthy markets result from the existence of land speculators; and (4) real estate prices increase rapidly, exceeding residents' ability to pay. Recently, to reduce these risks, central governments in developing countries began to recognize the inherent financial risks of land asset management at subnational levels and began to integrate land financing into the broader subnational financial management framework [12].

The literature shows that the unrestricted continuous deepening of land capitalization is destructive, and it should be limited. However, the concept, theory and mechanism of "limited land capitalization" remain vague. This is the focus of this paper, and the following theoretical analysis will discuss the existence of land capitalization limits and its economic effects.

\subsection{Theoretical Inference of the Existence of $A$ Limit}

Land economics became an independent discipline globally following the publication of The Principles of Land Economics by Ely and Morehouse (1926) [38]. Any independent discipline has its own unique analysis paradigms. The starting point of the research paradigm for land economics is the natural attributes of land. The natural attributes of land mainly include carrying capacity, scarcity, fixity and durability [38]. These attributes determine the particularities of the laws of land economics as well as the logic underlying analyses of problems related to land economics [31].

First, land carries everything. Land is necessary for human life and production and is endowed with production factor attributes because of its natural use value. Unlike other production factors, such as labor and capital, land cannot be replaced. No production activity can happen without land. Therefore, land is a necessary condition for the production of all products.

Second, land has the characteristics of durability. Early economists said that the powers of the soil could not be destroyed, but experience has shown that this is not strictly true. Fertility can be depleted if the proper scientific rotation of crops or fertilization is not conducted. Depletion, however, occurs only up to a certain point, which may be called the permanent level of fertility. Fire will destroy a crop or a building, but ordinarily it will not destroy the capacity of the land to produce another crop or to support another building. Other factors of production, such as labor and capital, have a limited service life, so their use value declines over time. The value of a labor force, for example, will disappear with death, and equipment will be depreciated because of wear and tear. The use value of land, however, does not decrease over time. On the contrary, as the population continues to grow, land scarcity has been increasing. Moreover, the location of land is fixed, and each piece of land is unique, which makes land use easy to monopolize.

Because land is a scarce and useful resource, people inevitably scramble for and occupy land, and land becomes property. Landowners either use the land to obtain output or lease or sell the land to obtain property income, giving rise to land assets and capital 
attributes. All in all, in the economic sense, land represents the unity of production factors, property, assets, and capital, which makes it a productive asset.

This above analysis implies a sequential logic: first, land is the factor of production, and second, it is a factor of property and capital. Therefore, the function of land capital cannot be separated from the function of land production factors. The former must be based on the latter.

On the one hand, land capitalization produces a large amount of land appreciation gains, which accelerates capital accumulation. On the other hand, land capitalization is accompanied by an increase in land prices. A moderate increase in land prices may be acceptable, but excessive increases will harm land users. In other words, excessive land capitalization harms the function of land-production factors. Therefore, land can be capitalized, but it should not be overcapitalized. Hence, there must be limits on the capitalization of land, and its operation should be reasonably controlled.

\subsection{Competition for Growth: Institutional Background of Land Capitalization in China}

To understand the development of land capitalization in China, it is necessary to understand China's special political and economic system [39]. Not only did the rise of land capitalization stem from this system, but the excessive development of land capitalization is also closely related to it. Figure 1 shows the analysis framework of this study.

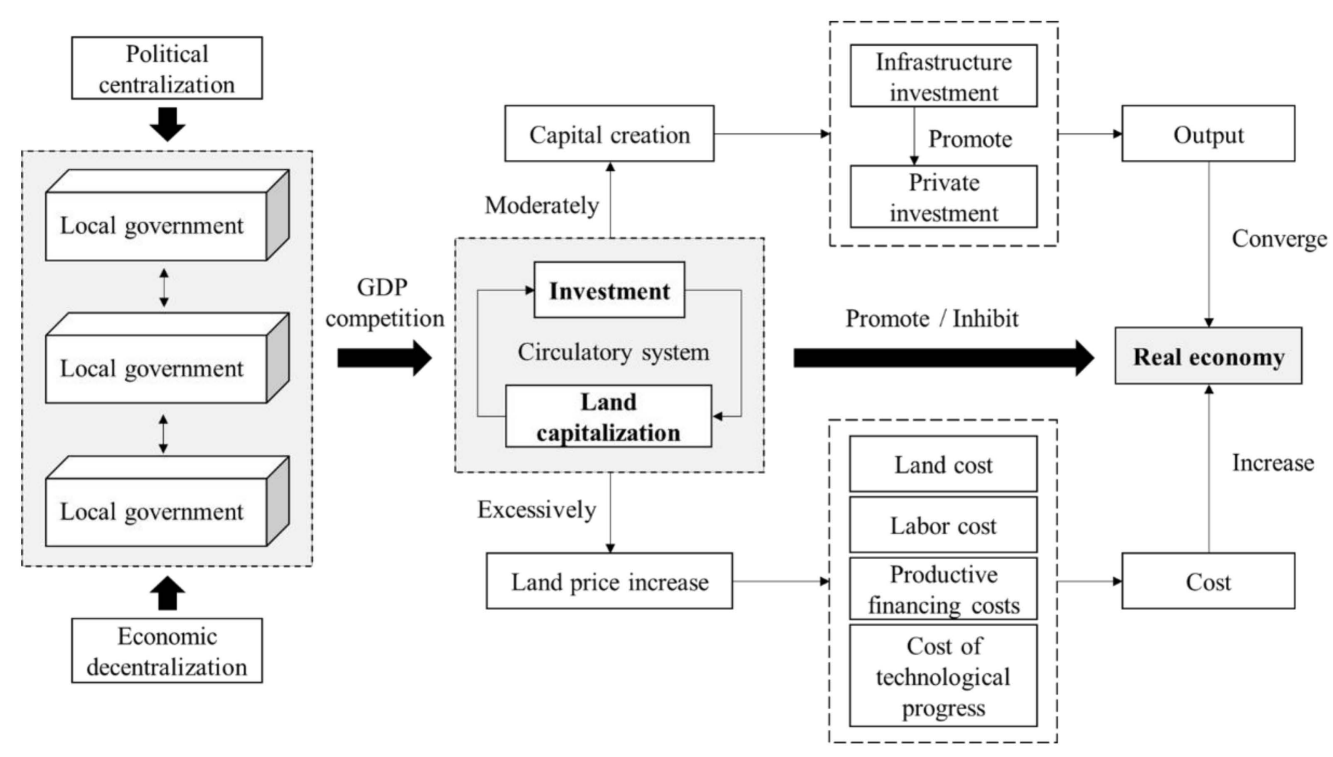

Figure 1. Impacts of land capitalization on the real economy (by the first author).

The basic feature of China's political and economic system is the combination of political centralization and economic decentralization [40]. This is completely different from the combination of fiscal decentralization and political federalism implemented by other developed economies (e.g., the United States), developing economies (e.g., India, Bolivia), and transition economies (e.g., Russia). In China, the central government has a strong ability to reward and punish local governments, and local officials must follow the policy guidance of the central government. To promote economic growth, the central government undertakes the political management of local governments through a GDPbased performance evaluation mechanism. Li and Zhou [41] confirmed that the political promotion of local officials is linked to the performance of local economic growth.

This system generates competition for growth among local governments and affects government behavior accordingly [42]. Local governments tend to be enthusiastic about increasing investment in pursuit of economic growth. Investment can not only achieve short-term economic growth, but can also attract private investment for more long-term growth $[24,31]$. A problem arises, however, with regard to how to obtain the large amount of capital needed to support investment. Capital scarcity has been the biggest problem 
faced by local governments, especially following the reform of the tax-sharing system in 1994 [28]. Local governments were forced to find new economic sources and soon started to focus on land. They found that, unlike traditional approaches, land capitalization could quickly accumulate capital in a short period of time. Thus, land-centered development has become the most significant feature of China's economic growth [23].

Most of the capital obtained by local governments through land capitalization is invested in the construction of urban infrastructure and industrial parks [12,39]. Good infrastructure attracts new investment and further promotes land appreciation, causing more land to be involved in the capitalization mechanism. Land capitalization has been gradually embedded in China's capital creation, forming a mutually supporting circular system of land capitalization and investment [43]. Circular effects can be both benign and vicious, and the two aspects can be transformed into each other depending on the degree of the process. In the moderate range, this cycle will bring about high economic growth Competition causes local governments to rely on this model for a long time and ignore possible adjustments. If this development mode is not adjusted in a timely manner, the circular effect will exceed the appropriate range, resulting in excessive land capitalization and excess investment.

\subsection{Influence Mechanism of Different Degrees of Land Capitalization on the Real Economy}

This analysis reveals that the degree of land capitalization can be categorized into two states-moderate and excessive-which produce different economic effects. Next, we specifically analyze how different degrees of land capitalization affect the real economy.

In the short-to medium-term, land capitalization within a moderate range will indeed create a huge amount of capital to stimulate an investment boom and high economic growth. Generally, capital that drives economic growth is classified as public capital or private capital; thus, it is appropriate to begin the analysis from the perspective of local governments and enterprises.

For local governments, large amounts of public capital have been accumulated through land capitalization, enabling capital-intensive infrastructure investment [44]. People and enterprises are attracted to good infrastructure, which will lead to positive externalities and increase the marginal output of enterprises [45]. For enterprises, land use rights obtained from the government are their most valuable asset. Rising land and housing prices have increased the mortgage value of land assets and real estate, which, in turn, have enhanced corporate financing capabilities. As a result, productive investment in the private sector will increase greatly, which is beneficial for increasing output. In short, both the public and private sectors are the beneficiaries of land capitalization. From a macro perspective, land capitalization has increased the supply of capital for the entire society, leading to a rapid expansion of capital per capita and ultimately promoting the formation of national capital and economic growth.

In the long run, land capitalization is also associated with significant costs because it enables more capital gains through rising land prices. The rise in land prices has led to a rise in the costs of land and housing, as well as the processes of production, logistics, warehousing, and sales. Moreover, land is closely related to other factors of production, and rising land prices will further cause abnormal increases in the cost of other factors.

First, labor costs will rise. The cost is ultimately recovered through product prices, which means the increase in land costs will increase the prices of daily consumer goods, including housing. With the increase in the cost of living in all aspects (e.g., food, clothing, housing, and transportation), the increase in labor wages is no longer the result of increased labor productivity but rather is driven by the increase in the cost of living, which further pushes the labor cost of the real economy [46]. According to the 2016 Global Manufacturing Competitiveness Index released by Deloitte, China's manufacturing wages rose from 8750 yuan in 2001 to 51,925 yuan in 2015, a nearly sixfold increase, far exceeding the GDP growth rate, and labor cost advantages were quickly lost. Such wage increases that 
are not based on increased labor productivity will inevitably reduce the competitiveness of enterprises.

Second, the costs of productive financing and technological progress have both risen. With the deepening of land capitalization, direct investment in real estate has become more profitable. Data from listed companies in 2008 show that the average profit rate of Chinese real estate companies was $28.7 \%$, whereas that of industrial enterprises was only $7.4 \%$ [47]. In a market economy, resources are allocated to high-profit sectors through market mechanisms; thus, most capital flows into the real estate industry instead of forming productive investments in the real economy [48]. For example, Wang and Rong [49] found that $60 \%$ of listed industrial enterprises owned real estate businesses in 35 key Chinese cities in 2007. When the capital of the real economy is occupied by the virtual economy, the productive financing cost of the real economy is relatively increased, which results in a decrease in effective investment and output [50]. Furthermore, the cost of technological progress also rises. Although enterprises need to balance physical investment and technological innovation investment, the latter is often risky. When greater constraints are placed on productive financing, the opportunity cost of technological innovation increases, and enterprises are more inclined to invest productive capital in real objects rather than technological research and development. This inhibits technological progress and restricts the long-term growth of the real economy.

In summary, land capitalization brings both output and cost. As shown in Figure 2, the law of diminishing marginal returns determines that output gradually converges, but at the same time, costs continue to increase. When the degree of land capitalization increases within a certain range $\left(\leq \theta^{*}\right)$, profits will increase, which is beneficial to the real economy; when the degree of land capitalization exceeds this range $\left(>\theta^{*}\right)$, profits decrease, which is harmful to the real economy. Accordingly, we propose the following hypothesis: land capitalization is limited, and within a certain limit, the growth of the real economy will be promoted; beyond that limit, it will be suppressed.

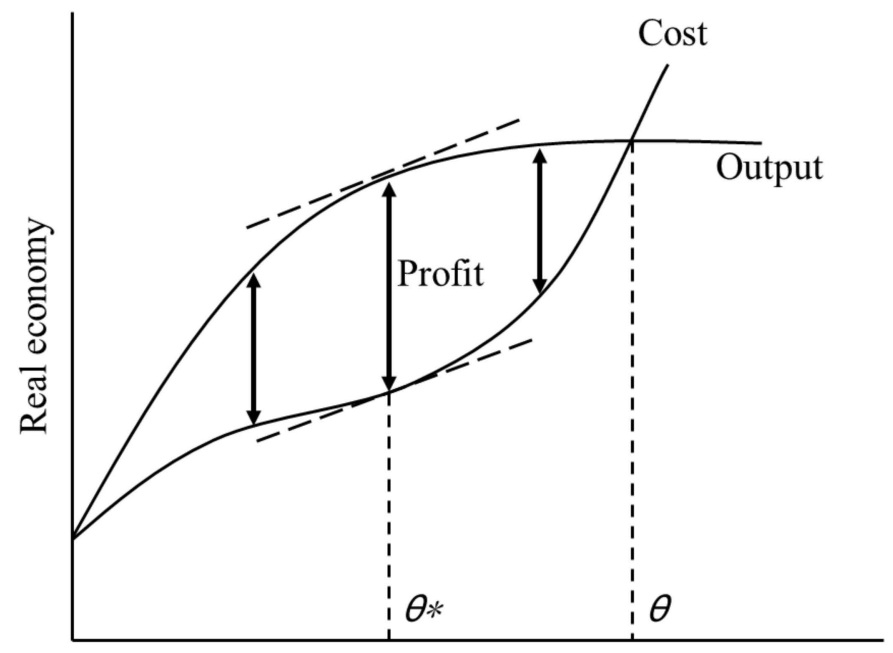

The degree of land capitalization

Figure 2. Analysis of the systemic benefits of land capitalization.

\section{Methods and Data}

We propose a new measurement method for land capitalization and describe the research methods and data sources. Note that the scope of this study is limited to residential land, because the driving force of land capitalization in China is mainly residential land. Industrial land, commercial land, and office land are all productive in nature, and their prices generally will not rise irrationally. This is because production and business activities will naturally withdraw under high land prices, making land prices return to normal levels. Various land uses can be clearly distinguished, even when speculation is involved. Because 
China has established a strict land use control system, once a piece of land is identified as industrial land, it cannot be transferred to other purposes, even if the residential land is profitable.

\subsection{Measuring the Degree of Land Capitalization}

The quantitative measurement of land capitalization is the premise for this empirical research. Usually, the land conveyance fee is used to measure the degree of land capitalization [31]. This is a rough method, however, because the value-added part of the land is not specifically extracted. A precise measurement should start from the definition of land capitalization-namely, the process of land appreciation in market transactions. "Value added" is the core connotation and external characteristic of capitalization. Therefore, the degree of land capitalization is externally manifested as the degree of land appreciation. The higher the degree of land appreciation, the greater the amount of created capital, and the higher the degree of land capitalization. Land appreciation refers to an increase in the value of land; land value includes basic value and premium value.

We drew on Capozza and Helsley [51] and Rhee [52] to propose a new quantitative measure of land capitalization based on the land value dichotomy. As shown in Figure 3, in the land value dichotomy, we divide the total land value into the land factor value and land capital value. The land factor value refers to the basic value of land as a factor of production and life. The land capital value refers to the part that exceeds the basic value caused by land appreciation after land is put into capital operation. A certain land capital value may be beneficial for revitalizing the economy, but if excessive speculation occurs, the land capital value will rise uncontrollably and lead to economic bubbles.

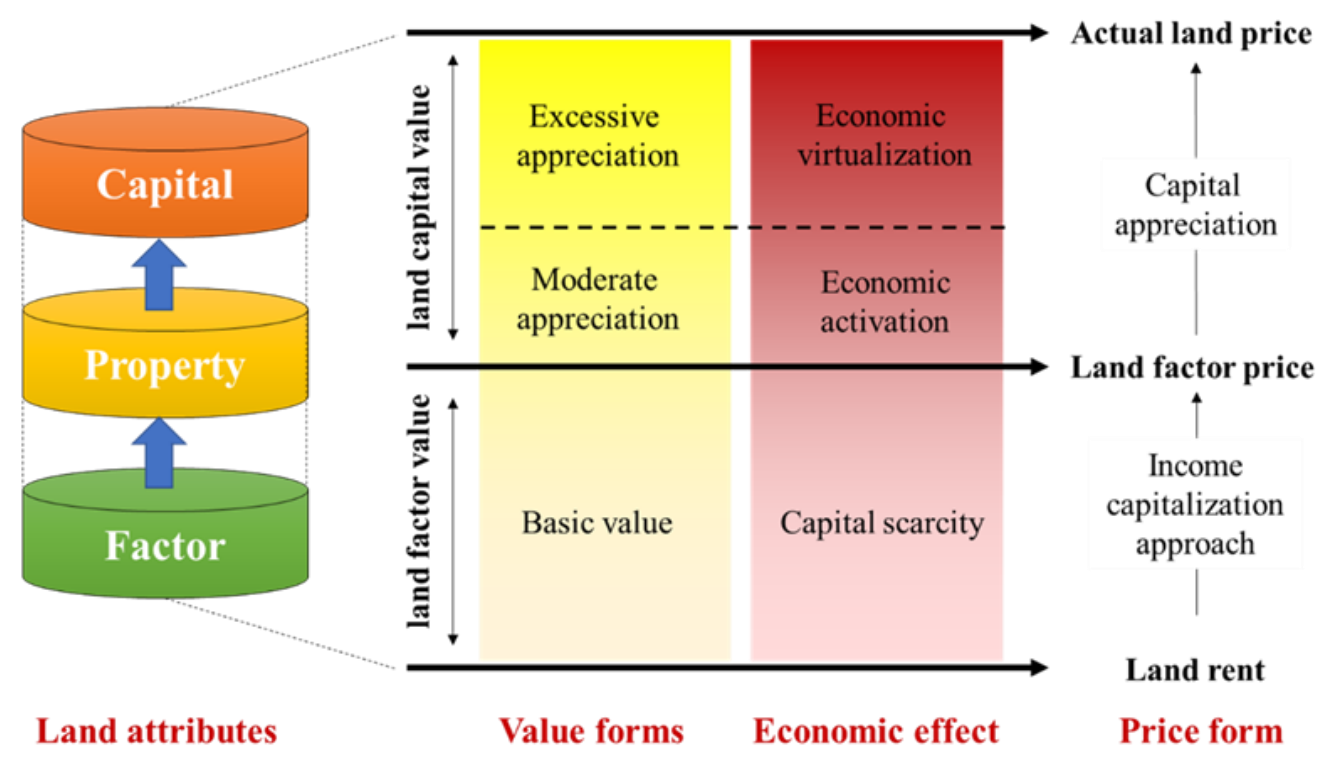

Figure 3. Dichotomy of land value.

On the basis of the land value dichotomy, we can measure the degree of land capitalization. In this study, we define the degree of land capitalization as the ratio of total land value to the land factor value. The larger the ratio is, the higher the degree of land capitalization is.

Total land value can be measured by the actual land price. Note that the actual land price is not the land lease price formed by auction but rather is the final land price paid by households. In real estate transactions, the land is transferred and value is added again. This means the actual land price must be extracted from the real estate selling price. Therefore, when we calculated the actual land price (total land value), we deducted the housing construction cost, taxes, and average social profits from the overall real estate selling price. Referring to Lin and Zhu [53], the average social profit rate and tax rate were set at $11 \%$ and $6 \%$, respectively. 
Following the basic principle that land price is the capitalization of land rent (income capitalization approach), the land factor value was calculated as the ratio of land rent to the rate of return. The reason for this is that although real estate prices often rise excessively, rents generally rise moderately in proportion to economic development fundamentals and residents' income. In other words, leasing represents real housing demand; thus, land price calculated according to rent excludes investment demand. Rent, therefore, is considered to reflect the original factor value. Nevertheless, land rent cannot be obtained in a straightforward way. We must deduct the rent of the house from the total rent of the real estate to extract the fraction belonging to land. The calculation process used the following parameters: in China, the transfer period of residential land use rights is 70 years, and so the income period was set as 70 years. On the basis of the method of safety interest rate plus risk adjustment value, the reduction rate of residential land was set to $7 \%$, and the building reduction rate was set to $9 \%$ (based on experience, the building reduction rate is generally two percentage points higher than the land reduction rate).

We collected the necessary data and measured the degree of land capitalization in 35 key cities in China. These cities are all provincial capital cities or otherwise important cities; are evenly distributed in the eastern, central, and western economic regions; and are typical representatives of Chinese cities. These 35 key cities also have resources for comprehensive data and statistics. The data for real estate selling prices and rent came from the China Real Estate Big Data Information Platform (https:/ /fdc.fang.com/creis/ (accessed on 22 November 2021)), and the data for housing construction cost came from the China Construction Project Cost Information Network (http:/ / www.cecn.org.cn/housing/ (accessed on 22 November 2021)).

Table 1 shows the calculation results (2008-2018). The larger the numerical value, the higher the degree of land capitalization. Figure 4 shows the spatial visualization of the results, and the bar graph represents the degree of land capitalization. The results show that the degree of land capitalization in China has rapidly increased since 2008, with the average value increasing from 1.44 in 2008 to 3.31 in 2018, representing an increase of $130 \%$. Eleven cities, including Beijing, had an average growth rate of $200 \%$. Another set of 11 cities, including Shanghai, had an average growth rate of $100 \%$. Thirteen cities, including Guangzhou, had an average growth rate below $100 \%$. Because of regional differences in economic and social development, there are significant differences in the degrees of land capitalization in the eastern, central, and western regions. The order of the average degree of land capitalization from high to low is eastern (3.67), western (3.14), and central (2.86), and the order for the growth rate is eastern $(160 \%)$, central $(115 \%)$, and western $(97 \%)$. The changing trends in land capitalization in the 35 cities are consistent with intuition. The continuous deepening of China's land capitalization is a result of the rapid development of the real estate market. Because of the imperfect real estate tax system, the real estate market is conducive to speculation, and rising housing prices also have contributed to the continuous appreciation of land.

Table 1. Land capitalization in 35 key cities in China.

\begin{tabular}{cccccccccccc}
\hline City & $\mathbf{2 0 0 8}$ & $\mathbf{2 0 0 9}$ & $\mathbf{2 0 1 0}$ & $\mathbf{2 0 1 1}$ & $\mathbf{2 0 1 2}$ & $\mathbf{2 0 1 3}$ & $\mathbf{2 0 1 4}$ & $\mathbf{2 0 1 5}$ & $\mathbf{2 0 1 6}$ & $\mathbf{2 0 1 7}$ & $\mathbf{2 0 1 8}$ \\
\hline Beijing & 1.09 & 1.16 & 1.87 & 1.74 & 2.01 & 2.55 & 2.31 & 2.32 & 3.33 & 3.38 & 3.42 \\
Tianjin & 1.31 & 1.52 & 2.05 & 2.20 & 2.50 & 2.60 & 2.59 & 2.54 & 2.80 & 3.50 & 3.51 \\
Shijiazhuang & 1.11 & 1.68 & 1.61 & 1.74 & 1.89 & 2.03 & 2.46 & 2.97 & 3.59 & 4.28 & 3.77 \\
Taiyuan & 1.15 & 2.30 & 3.27 & 3.01 & 2.59 & 2.58 & 2.53 & 2.42 & 2.50 & 2.76 & 3.54 \\
Hohhot & 1.85 & 3.12 & 3.82 & 3.87 & 3.53 & 3.18 & 2.28 & 2.46 & 3.15 & 3.71 & 5.06 \\
Shenyang & 1.10 & 1.26 & 1.59 & 1.84 & 1.85 & 1.97 & 1.86 & 1.83 & 1.96 & 2.26 & 2.66 \\
Dalian & 1.65 & 1.74 & 2.21 & 2.37 & 1.94 & 1.95 & 1.96 & 1.98 & 2.01 & 2.25 & 2.52 \\
Changchun & 1.23 & 1.56 & 1.85 & 1.88 & 1.79 & 1.80 & 1.77 & 1.69 & 1.65 & 2.00 & 2.25 \\
Harbin & 1.03 & 1.08 & 1.20 & 1.08 & 1.10 & 1.10 & 1.40 & 1.36 & 1.39 & 1.65 & 1.55 \\
Shanghai & 1.27 & 1.53 & 2.11 & 2.05 & 2.15 & 2.73 & 2.63 & 2.79 & 3.90 & 3.75 & 3.78 \\
Nanjing & 1.27 & 1.55 & 2.18 & 2.18 & 2.12 & 2.48 & 2.48 & 2.50 & 3.31 & 3.39 & 3.62 \\
Hangzhou & 1.99 & 1.97 & 3.00 & 2.67 & 2.15 & 2.50 & 2.40 & 2.44 & 2.74 & 3.17 & 4.38 \\
\hline
\end{tabular}


Table 1. Cont.

\begin{tabular}{|c|c|c|c|c|c|c|c|c|c|c|c|}
\hline City & 2008 & 2009 & 2010 & 2011 & 2012 & 2013 & 2014 & 2015 & 2016 & 2017 & 2018 \\
\hline Ningbo & 2.23 & 2.85 & 4.24 & 3.52 & 3.30 & 3.18 & 2.85 & 2.75 & 3.08 & 3.54 & 4.77 \\
\hline Hefei & 1.55 & 1.46 & 1.64 & 1.60 & 1.73 & 1.76 & 1.83 & 2.03 & 2.78 & 2.71 & 2.97 \\
\hline Fuzhou & 1.35 & 1.34 & 2.09 & 2.61 & 2.58 & 2.98 & 2.69 & 2.46 & 2.68 & 3.20 & 4.57 \\
\hline Xiamen & 1.56 & 1.27 & 1.69 & 2.01 & 2.25 & 2.46 & 2.61 & 2.89 & 3.51 & 4.68 & 4.88 \\
\hline Nanchang & 2.01 & 1.69 & 2.26 & 3.07 & 2.63 & 2.87 & 2.49 & 2.61 & 2.69 & 2.87 & 3.24 \\
\hline Qingdao & 1.84 & 1.61 & 1.73 & 1.64 & 1.61 & 1.80 & 2.06 & 2.17 & 1.95 & 1.99 & 2.60 \\
\hline Jinan & 1.31 & 1.49 & 2.07 & 2.08 & 1.97 & 1.97 & 1.92 & 2.03 & 2.25 & 2.71 & 4.07 \\
\hline Zhengzhou & 1.02 & 1.06 & 1.37 & 1.47 & 1.69 & 1.88 & 1.94 & 2.08 & 2.27 & 2.72 & 3.10 \\
\hline Wuhan & 1.14 & 1.11 & 1.39 & 1.38 & 1.31 & 1.42 & 1.46 & 1.66 & 1.67 & 1.76 & 1.76 \\
\hline Changsha & 1.00 & 1.10 & 1.16 & 1.52 & 1.61 & 1.58 & 1.41 & 1.26 & 1.38 & 1.64 & 2.24 \\
\hline Guangzhou & 1.40 & 1.39 & 1.88 & 1.84 & 1.88 & 1.85 & 1.79 & 1.69 & 1.81 & 1.76 & 2.38 \\
\hline Shenzhen & 1.10 & 1.32 & 1.45 & 1.41 & 1.55 & 1.91 & 2.08 & 2.98 & 3.00 & 3.65 & 3.78 \\
\hline Nanning & 1.24 & 1.52 & 1.81 & 1.92 & 1.63 & 1.69 & 1.60 & 1.47 & 1.62 & 2.33 & 2.43 \\
\hline Haikou & 1.04 & 1.41 & 2.31 & 2.86 & 2.45 & 2.64 & 2.68 & 2.34 & 2.45 & 3.59 & 4.10 \\
\hline Chongqing & 1.23 & 1.03 & 1.36 & 1.61 & 1.49 & 1.57 & 1.45 & 1.43 & 1.42 & 1.96 & 2.50 \\
\hline Chengdu & 1.80 & 1.51 & 2.01 & 2.01 & 1.86 & 1.94 & 1.85 & 1.25 & 1.38 & 1.62 & 1.89 \\
\hline Guiyang & 1.42 & 1.38 & 1.46 & 1.66 & 1.44 & 1.36 & 1.31 & 1.41 & 1.49 & 2.07 & 3.28 \\
\hline Kunming & 1.21 & 1.28 & 1.13 & 1.55 & 1.94 & 1.83 & 1.89 & 1.99 & 2.10 & 2.68 & 3.58 \\
\hline Xi'an & 1.46 & 1.48 & 1.79 & 1.90 & 1.91 & 2.21 & 1.85 & 1.80 & 2.00 & 2.84 & 4.71 \\
\hline Lanzhou & 2.43 & 2.96 & 2.67 & 2.83 & 2.81 & 2.83 & 3.13 & 2.51 & 2.64 & 2.94 & 3.42 \\
\hline Xining & 2.23 & 1.34 & 1.67 & 1.41 & 1.98 & 1.68 & 1.62 & 1.28 & 2.13 & 2.28 & 2.85 \\
\hline Yinchuan & 1.39 & 1.88 & 2.13 & 2.75 & 3.80 & 3.14 & 2.51 & 3.54 & 3.50 & 3.49 & 4.23 \\
\hline Urumqi & 1.46 & 1.63 & 1.82 & 1.79 & 1.86 & 2.16 & 2.00 & 1.83 & 1.70 & 1.91 & 2.47 \\
\hline Nationwide & 1.44 & 1.59 & 2.00 & 2.09 & 2.08 & 2.18 & 2.10 & 2.14 & 2.39 & 2.77 & 3.31 \\
\hline Eastern Region & 1.41 & 1.57 & 2.13 & 2.17 & 2.14 & 2.35 & 2.34 & 2.42 & 2.77 & 3.19 & 3.67 \\
\hline Central Region & 1.33 & 1.61 & 2.00 & 2.10 & 2.00 & 2.02 & 1.90 & 1.95 & 2.16 & 2.42 & 2.86 \\
\hline Western Region & 1.59 & 1.60 & 1.78 & 1.94 & 2.07 & 2.04 & 1.92 & 1.85 & 2.00 & 2.41 & 3.14 \\
\hline
\end{tabular}

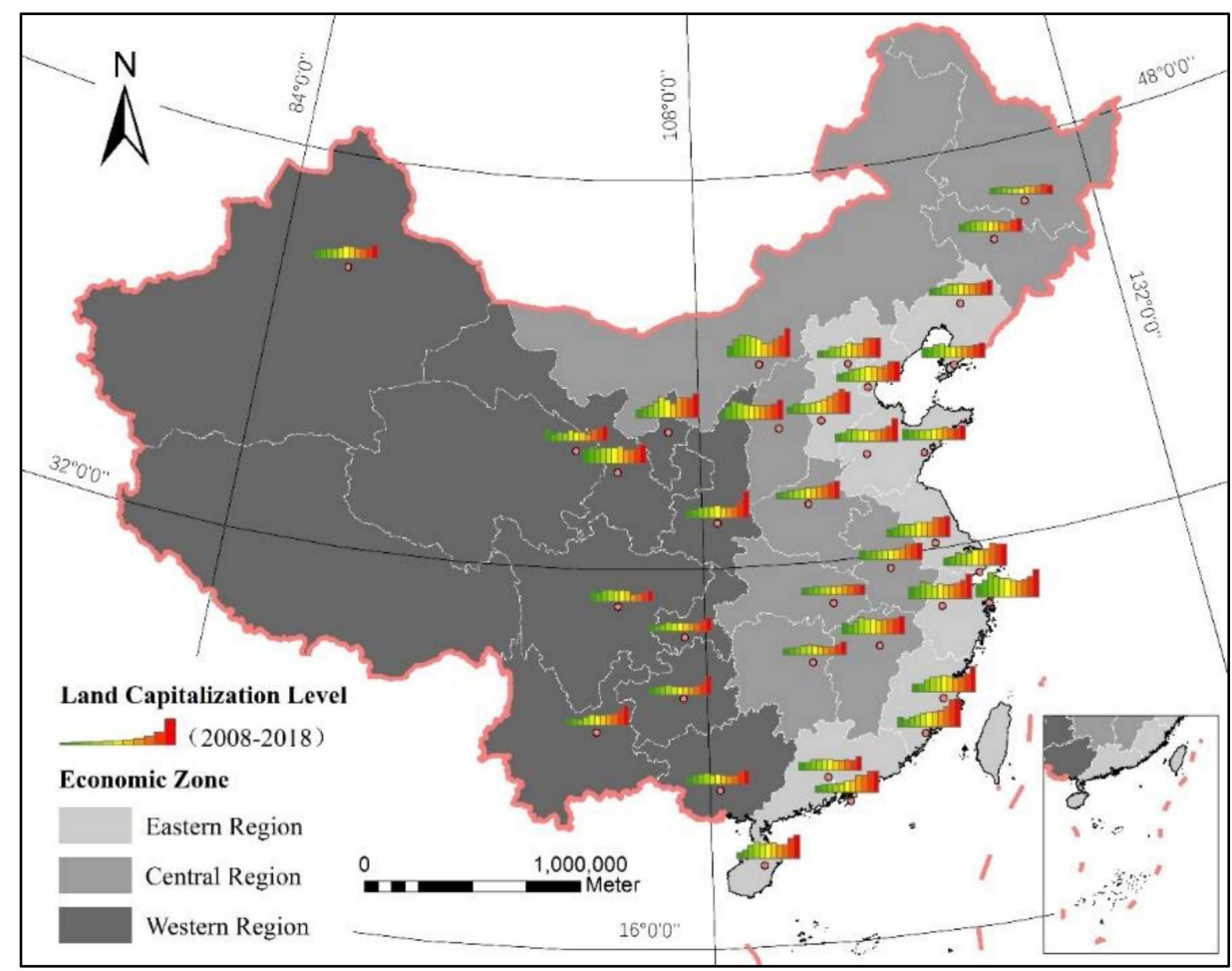

Figure 4. Land capitalization in 35 key cities in China. 


\subsection{Model Settings}

Our theoretical analysis indicated that there are reasonable limits to land capitalization. Within those limits, land capitalization can promote the real economy, but excessive development beyond these limits harms the growth of the real economy. This means that the relationship between land capitalization and real economic growth has an inverted-U shape - that is, it initially promotes growth to a point and then suppresses growth. To prove this hypothesis, we conducted an empirical test based on panel data from 2008 to 2018 for 35 key cities in China. We chose 2008 as the starting point because after the 2008 financial crisis, Chinese local governments established a large number of financing platforms, and the scale of land mortgage loans expanded rapidly, which greatly promoted the process of land capitalization. In addition, because of the impact of COVID-19, China's economic data after 2019 have fluctuated too abnormally to be used. Equation (1) is the empirical regression model that we constructed, where the dependent variable is the output of the real economy, the core independent variable is the degree of land capitalization, and the square term of land capitalization is added to the right side of the equation to verify the inverted-U relationship. In reality, it usually takes time from capital investment to economic growth. Therefore, we lagged the core independent variable by one year, which also solved the endogeneity problem caused by potential two-way causality. The regression model is as follows:

$$
\text { lnreal }_{\mathrm{it}}=\alpha_{0}+\alpha_{1} \text { lcap }_{\mathrm{it}-1}+\alpha_{2} \text { lcap }_{\mathrm{it}-1}{ }^{2}+\text { Bcontrols }_{\mathrm{it}}+\mu_{\mathrm{i}}+\varepsilon_{\mathrm{it}}
$$

where $\mathrm{i}$ is the city, $\mathrm{t}$ is time, lnreal is the logarithm of real economic output, lcap is the degree of land capitalization, controls is a set of control variables that have a significant effect on the growth of the real economy, $\mu$ is the individual fixed effect, and $\varepsilon$ is a random error term.

\subsection{Variables and Data}

The dependent variable was the real economic output (lnreal), which was obtained by deducting the real estate industry added value, financial industry added value, and primary industry added value from the GDP. The core independent variable was the degree of land capitalization (lcap), which was introduced in Section 3.1. The control variables included labor (lnlabor), capital (lninvest), land factors (lnland), technological progress (lntech), economic openness to the outside world (open), and resource endowment (resour), all of which promote real economic growth. To accurately represent the labor input of the real economy, we deducted the labor of the real estate and financial industries from the total labor. Capital investment was expressed as fixed asset investment, which was obtained by deducting real estate development investment from the total fixed asset investment of the entire society. Because production requires the support of land factors, land factor variables are necessary. The input of land factors was expressed as the cumulative built-up area. The land factor variables are essential because they have a strong correlation with the degree of land capitalization; neglecting them results in the endogeneity problem of missing variables. Technological progress was expressed as annual patent grants. The level of openness to the outside world is related to foreign trade and has a significant impact on the real economy. It was represented by total imports and exports. Resource endowment greatly affects the urban real economy and was expressed as the proportion of the number of employees in extractive industries in total employment. Extractive industry is an industrial sector that directly extracts various resources from the natural world. The large number of people employed in the extractive industry means that the city is rich in resources. Therefore, the employment share of extractive industries is a good proxy indicator of resource endowment. Real estate prices and rent data were obtained from the Chinese Research Data Services Platform (www.cnrds.com (accessed on 22 November 2021)) and the Wind Database (www.wind.com.cn (accessed on 22 November 2021)). Statistical data regarding prefecture-level cities were obtained from the cities' statistical yearbooks. To eliminate the effects of price factors, we set the base price to be that in 2008 . We 
used the GDP deflator, consumer price index, and fixed asset price index to convert economic indicators such as real economic output, real estate price and rent, and fixed asset investment. To eliminate heteroscedasticity, we conducted logarithmization on some variables. Table 2 shows the descriptive statistics of the variables.

Table 2. Variable descriptions and statistics.

\begin{tabular}{cccccc}
\hline Variable & Obs & Mean & Std. Dev & Min & Max \\
\hline lnreal & 385 & 17.403 & 0.871 & 15.078 & 19.250 \\
lcap & 385 & 2.078 & 0.697 & 1.003 & 4.676 \\
lnlabor & 385 & 4.794 & 0.744 & 3.142 & 6.571 \\
lninvest & 385 & 16.788 & 0.803 & 14.206 & 18.713 \\
lnland & 385 & 5.919 & 0.642 & 4.173 & 7.277 \\
lntech & 385 & 8.767 & 1.372 & 5.342 & 11.576 \\
open & 385 & 14.430 & 1.594 & 10.701 & 17.800 \\
resour & 385 & 1.386 & 2.670 & 0.000 & 17.121 \\
\hline
\end{tabular}

\section{Empirical Results and Analysis}

\subsection{Regression Results}

The sample cities in this study are in different regions, and the differences between them are significant. The F-test showed that the individual effects of the panel data were clear and strongly rejected pooled ordinary least-squares estimation. The Hausman test showed that the fixed effects model was more consistent with the statistical characteristics of the data than the random effects model. Therefore, we mainly undertook an analysis based on the fixed effects model (Model 1), but we also report the results of the random effects model (Model 2) and maximum likelihood estimation (Model 3). We adopted cluster-robust standard errors to solve the problem of heteroscedasticity.

The regression results in Table 3 show that the linear term of land capitalization is significantly positive at the significance level of $1 \%$, and the square term is significantly negative at the level of $5 \%$, indicating that the degree of land capitalization has a significant inverted-U relationship with the output of the real economy, thus supporting our theoretical hypothesis. The calculation based on the regression coefficients showed that the threshold of the structural change effect was 3.5. This threshold indicates that when the actual land price is equal to 3.5 times the land factor value-that is, when the land capital value is equal to 2.5 times the land factor value-land capitalization begins to show a significant inhibitory effect on real economic growth, and excessive capitalization of land beyond this threshold harms real economic growth. Therefore, when the level of land capitalization exceeds this threshold, we define it as overcapitalization.

Table 3. Regression results.

\begin{tabular}{|c|c|c|c|}
\hline Independent Variable & $\begin{array}{c}\text { Model } 1 \\
\text { (FE) }\end{array}$ & $\begin{array}{c}\text { Model } 2 \\
\text { (RE) }\end{array}$ & $\begin{array}{l}\text { Model } 3 \\
\text { (MLE) }\end{array}$ \\
\hline \multirow[b]{2}{*}{ lcap t-1 } & $0.219^{* * *}$ & $0.205^{* * *}$ & $0.207^{* * *}$ \\
\hline & $(0.070)$ & $(0.068)$ & $(0.053)$ \\
\hline \multirow{2}{*}{$\operatorname{lcap}_{\mathrm{t}-1^{2}}$} & $-0.031^{* *}$ & $-0.028^{* *}$ & $-0.028^{* * *}$ \\
\hline & $(0.014)$ & $(0.014)$ & (0.011) \\
\hline \multirow{2}{*}{ lnlabor } & $0.240^{* * *}$ & $0.234^{* * *}$ & $0.235^{* * *}$ \\
\hline & $(0.039)$ & $(0.039)$ & $(0.037)$ \\
\hline \multirow{2}{*}{ lninvest } & $0.186^{* * *}$ & $0.196^{* * *}$ & $0.195^{* * *}$ \\
\hline & $(0.042)$ & $(0.039)$ & $(0.020)$ \\
\hline \multirow{2}{*}{ lnland } & $0.373^{* * *}$ & $0.378^{* * *}$ & $0.378^{* * *}$ \\
\hline & $(0.112)$ & $(0.091)$ & $(0.051)$ \\
\hline \multirow{2}{*}{ lntech } & $0.181^{* * *}$ & $0.176^{* * *}$ & $0.177^{* * *}$ \\
\hline & $(0.036)$ & $(0.032)$ & $(0.021)$ \\
\hline \multirow{2}{*}{ open } & $0.042^{* *}$ & $0.044^{* * *}$ & $0.044^{* * *}$ \\
\hline & $(0.017)$ & (0.014) & $(0.014)$ \\
\hline \multirow{2}{*}{ resour } & -0.004 & -0.005 & -0.005 \\
\hline & $(0.005)$ & $(0.005)$ & $(0.005)$ \\
\hline $\mathrm{R}^{2}$ & 0.9249 & 0.9248 & \\
\hline F-statistic/Wald-statistic/LR-statistic & 179.39 & 1588.02 & 830.62 \\
\hline
\end{tabular}


The control variables (i.e., labor, capital, land factors, technological progress, and openness) all significantly promoted the growth of the real economy at the level of $1 \%$, which is in line with theoretical expectations. The magnitudes of the regression coefficients were reasonable. Interestingly, resource endowment did not significantly promote real economic growth. Its regression coefficient was -0.004 , suggesting that abundant resource conditions do not necessarily bring real economic growth but rather may be associated with a resource curse.

\subsection{Risk Analysis of Excessive Land Capitalization}

On the basis of the threshold of the degree of land capitalization, we inspected the state of land capitalization in the sample cities. The results for the degree of land capitalization shown in Table 1 indicate that the national average degree of land capitalization in 2018 reached 3.31, which is very close to the threshold. The eastern region in particular has exceeded the threshold and entered a state of overcapitalization, and the central and western regions have reached $82 \%$ and $90 \%$ of the threshold. This result is consistent with intuition. Because of its good location, the eastern region has led the country's economic rise. The explosive growth of the region and its real estate market has caused a steep rise in land prices, which may lead to an overheating of the economy and the excessive capitalization of land. Although the economic development of the central region is ahead of the western region, the land capitalization level of the western region is higher than that of the central region. The reason is that when the central and western regions adopted the model of land-driven development, the underdeveloped western region pursued more aggressive development, which decoupled land capitalization from economic fundamentals.

Figure 5 presents the degree of land capitalization in all sample cities in the form of scattered points. It shows that the average degree of land capitalization in China is accelerating and approaching the threshold of excessive land capitalization. There were two upsurges in the overcapitalization of land. The first appeared during 2010-2012, which may have been related to the expansion of land supply and loose monetary policy in the context of the financial crisis. The second climax occurred from 2015 to 2018, when the number of cities entering a state of overcapitalization increased rapidly. Because of the slowdown in economic growth in many cities during this period, the development model of land capitalization gradually lost the support of high economic growth. As of 2018, 16 sample cities had entered a state of overcapitalization. According to the development trend, we can predict that this number may increase. These key cities are regional economic growth fulcrums and the components of China's regional economic framework. If and when these important economic fulcrums are affected by the excessive capitalization of land, the overall national economic framework will be out of balance. This will lead to a recession in the real economy and harm China's economic growth prospects. Therefore, the current state of risk warrants attention from policymakers.

Figure 6 shows the kernel density distribution of real economic output under moderate and excessive land capitalization degrees. When in a moderate state, most observations of real economic output are at a high level. However, when land capitalization changes from moderate to excessive, the probability of high real economic output observations decreases notably. This clearly shows that the excessive development of land capitalization does have a negative impact on the real economy. 


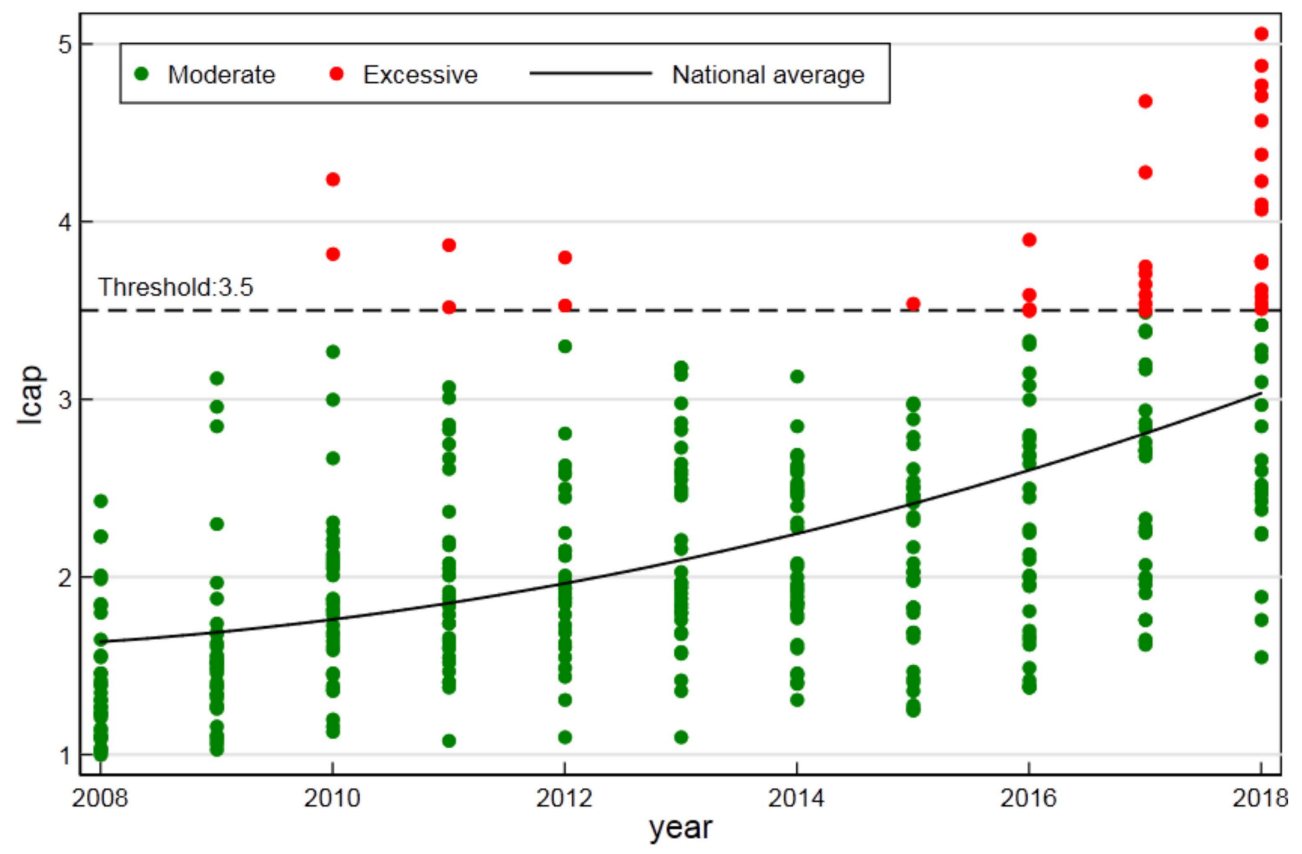

Figure 5. Development trend of land capitalization in the sample cities.

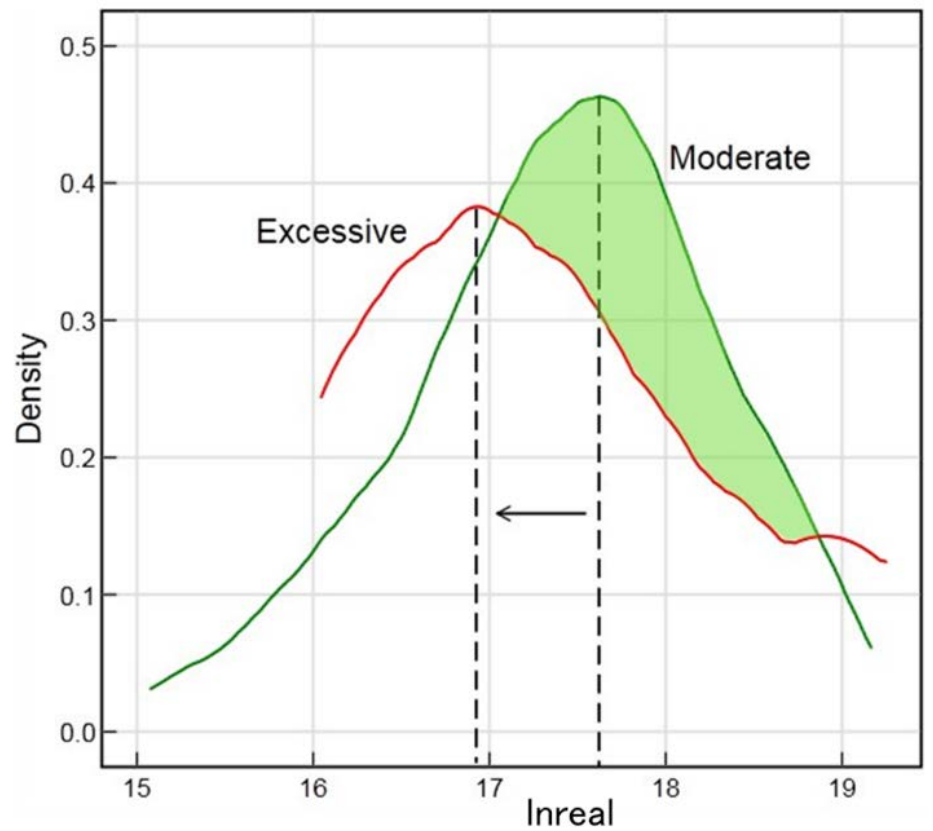

Figure 6. Kernel density estimation of output under different degrees of land capitalization.

\section{Excessive Land Capitalization: Analysis of Causes}

Although there are significant differences in the natural, economic, and social aspects of the 35 surveyed cities, the land capitalization of each city followed the same upward trend. Many cities have entered a state of excessive capitalization. This general phenomenon implies that the process of land capitalization in various cities may be promoted by a common macro mechanism. As mentioned in the theoretical analysis, this may be attributed to China's special decentralized system. To verify this, we first need to quantify the macro system based on political and economic dimensions.

The three perspectives of fiscal revenue, fiscal expenditure, and fiscal autonomy often are used to measure the degree of central-local fiscal decentralization in the existing literature. The fiscal revenue and expenditure perspective is applicable to time series data, whereas fiscal autonomy is applicable to cross-sectional data or panel data that contain 
regional differences [54]. Therefore, this study chose the index of fiscal autonomy to measure the degree of fiscal decentralization. With reference to Zhou et al. [55], fiscal autonomy is expressed as local general budget revenue/local general budget expenditure. The relevant statistics were obtained from the China Urban Statistical Yearbook.

Political centralization is reflected in performance evaluations, which stimulate economic competition among local governments. To promote economic growth and successfully compete, local governments compete to attract investment. Because foreign direct investment often brings abundant capital and advanced technology, it has become a focus of competition among local governments. Therefore, the number of foreign direct investment projects reflects local governments' efforts to compete economically [40], indirectly reflecting the intensity of intergovernmental competition. Therefore, this study used the number of foreign direct investment projects to describe the intensity of political competition. Data on foreign direct investment were collected from the China Urban Statistical Yearbook.

To verify the effect of Chinese-style decentralization on land capitalization, a regression model was constructed as follows:

$$
\text { lcap }_{\text {it }}=\alpha_{0}+\alpha_{1} \text { dece }_{i t}+\alpha_{2} \text { compete }_{i t}+\beta_{\text {controls }_{i t}}+\mu_{\mathrm{i}}+\varepsilon_{\mathrm{it}}
$$

where $i$ is the city, $t$ is time, lcap is the degree of land capitalization, dece is the degree of fiscal decentralization, compete is the degree of intensity of political competition, controls is a set of control variables that significantly affect land capitalization (including per capita GDP (pgdp), urbanization (urban), infrastructure status (road), and population density (pop)), $\mu$ is the individual fixed effect, and $\varepsilon$ is a random error term.

Table 4 reports the results of the random effects model (Model 4), fixed effects model (Model 5), and the generalized method of moments estimation (Model 6). Regardless of which model is used, the degree of land capitalization is positively correlated with the degree of fiscal decentralization and the intensity of political competition. This correlation indicates that China's unique decentralized system has indeed promoted the development of land capitalization. It also confirms the logic whereby local governments pursue land capitalization to develop their economies, successfully compete, and secure promotionwhich, in turn, leads to an increase in the degree of land capitalization. We can predict that if the performance appraisal mechanism, based on the pursuit of high growth, continues to operate, the degree of land capitalization will continue to rise, leading to more cities entering a state of overcapitalization. Therefore, adjusting the development model from high growth to high quality is a strategic choice that can help solve the problem of overcapitalization.

Table 4. Impact of Chinese-style decentralization on land capitalization.

\begin{tabular}{|c|c|c|c|}
\hline Independent Variable & $\underset{\text { (RE) }}{\text { Model } 4}$ & $\begin{array}{c}\text { Model } 5 \\
\text { (FE) }\end{array}$ & $\begin{array}{c}\text { Model } 6 \\
\text { (SYS-GMM) }\end{array}$ \\
\hline dece & $0.746^{* * *}$ & $0.605^{* * *}$ & $\begin{array}{l}0.525^{* * * *} \\
(0.098)\end{array}$ \\
\hline compete & $\begin{array}{l}0.124^{* *} \\
(0.050)\end{array}$ & $\begin{array}{c}0.378^{* * *} \\
(0.071)\end{array}$ & $\begin{array}{c}0.138^{* * * * *} \\
(0.039)\end{array}$ \\
\hline pgdp & $\begin{array}{c}0.080^{* * *} \\
(0.011)\end{array}$ & $\begin{array}{c}0.073^{* * *} \\
(0.011)\end{array}$ & $\begin{array}{c}0.011 \\
(0.008)\end{array}$ \\
\hline urban & $\begin{array}{c}1.103^{* * *} \\
(0.353)\end{array}$ & $\begin{array}{c}2.116^{* * *} \\
(0.500)\end{array}$ & $\begin{array}{l}0.712^{* *} \\
(0.303)\end{array}$ \\
\hline road & $\begin{array}{c}0.056^{* * *} \\
(0.012)\end{array}$ & $\begin{array}{c}0.067^{* * *} \\
(0.014)\end{array}$ & $\begin{array}{l}0.0198^{*} \\
(0.010)\end{array}$ \\
\hline pop & $\begin{array}{l}0.0315 \\
(0.081)\end{array}$ & $\begin{array}{c}0.025 \\
(0.091)\end{array}$ & $\begin{array}{l}0.119^{*} \\
(0.071)\end{array}$ \\
\hline L.lcap & & & $\begin{array}{l}0.907 * * * \\
(0.038)\end{array}$ \\
\hline$R^{2}$ & 0.381 & 0.408 & \\
\hline F-statistic/Wald-statistic & 180.65 & 39.54 & 1240.36 \\
\hline
\end{tabular}




\section{Discussion}

Since the late 1970s, neoliberal economics has emerged, emphasizing laissez-faire theories and policies [56]. The market is not omnipotent, however, and the risks of market failure and excessive marketization cannot be ignored. Regarding land, unilateral emphasis on marketization and capitalization may undermine its basic public function and production factor function. Therefore, this study proposed taking another look at the relationship between land capitalization and national economic development. We proposed "the limits to land capitalization," which means that land capitalization is not always beneficial, and its economic effects vary with its degree. In a moderate range, it is conducive to capital accumulation and the growth of the real economy; in an excessive state, it may lead to the recession of the real economy.

The results of this study arouse our doubts about promoting land capitalization through formalization $[4,57]$. This practice has brought some unexpected economic consequences. In addition to the real economic depression we found, it also includes the livelihood difficulties of vulnerable groups and the increase of land ownership inequality [33], because land capitalization always benefits people with purchasing power [58]. As the World Bank [59] survey found, in the reforms of Southeast Asian countries, the land distribution was almost equal at the beginning of the reform, but the current inequality is very high (Gini coefficient of land distribution: 0.65 ). Together, these results challenge the traditional view of thorough formalization and marketization.

We hold a view of limited capitalization similar to Harvey [3]. The tendency of land to be increasingly regarded as a pure financial asset is effective for capital because it coordinates the generation of surplus value and distributes land use in a way that is easy to accumulate, but this process is not without contradiction, especially when the land is subject to speculation and monopoly control. Therefore, as Christopher [60] pointed out, caution is not just advisable but necessary.

In addition, the empirical investigation of government behavior shows that local government is the leading force to promote land capitalization, which supports Christopher's [6] view on national public land capitalization. The state, like other actors, also treats its own land as a financial asset, and this trend is popular around the world [35,61]. Government finance benefited from land capitalization, so it actively and directly contributed to this trend. Because of the existence of financial incentives, this motivation of the state can easily lead to excessive capitalization of land. Therefore, we suggest that the government should return to public functions and play its due role in regulating the speculation that often plagues the land market. Because of the existence of financial incentives, this motivation of the state can easily lead to excessive land capitalization. Therefore, we suggest that the government should return to public functions and play an important role in curbing land speculation [7].

To get an idea of the global position of China's land capitalization level, we should link the findings of this paper with other countries and cities for comparative analysis. The World Bank [12] provides a comparison of the financing magnitude of international land capitalization. Compared with other countries and regions, the scale of land capitalization financing in China is far ahead of others. Figure 5 also shows that the overall degree of land capitalization in China is approaching the excessive threshold, and some cities have even broken through the threshold. Therefore, it can be inferred that the degree of land capitalization in China may be at the forefront globally, and its excessive capitalization may be quite extreme. Of course, a more accurate comparison needs to be based on a unified measurement method. Therefore, using the same method to measure the capitalization of other countries and cities is meaningful follow-up work that needs to be explored.

\section{Conclusions and Implications}

Unlike previous work on land capitalization, this study found that land capitalization is not a binary issue (positive vs. negative) but rather is a matter of degree. We theoretically proposed the existence of limits to land capitalization and empirically tested the hypothesis 
using data from 35 cities in China. The conclusions were as follows: (1) land has multiple economic functions (e.g., factors of production, property, and capital), and excessive use of the capital function can affect its basic function as a production factor. Therefore, there is a limit to land capitalization, and the overuse of land's capital function should be controlled. (2) The degree of land capitalization directly affects the growth performance of the real economy. Moderate land capitalization has a positive effect on the growth of the real economy, whereas excessive land capitalization harms it. (3) The unique Chinese-style decentralized system has promoted the deepening of land capitalization, and many key cities in China have entered a state of excessive land capitalization. This trend will cause a recession in the real economy and affect the growth prospects of China's economy.

Although China's economy boomed as a result of land marketization and capitalization, in recent years, it has faced difficulties related to overcapitalization. This suggests that it is important to undertake land-related market-oriented reforms in the process of economic transition. The appropriate use of market mechanisms can achieve the efficient allocation of land resources and sustainably activate the economy. However, land is also a special production factor, and radical market-oriented reforms will lead to excessive capitalization, which is particularly risky for transition economies. For China, therefore, it is recommended that future land reforms seek to prevent excessive capitalization and excessively high prices to mitigate the negative effects on land production functions and promote social stability.

For cities with serious overcapitalization of land, the problem should be addressed by reforming systems and mechanisms. First, policymakers should promote political and economic reforms that will release local governments from their overreliance on land capitalization. In terms of political management, the performance evaluation mechanism should be reformed. Performance evaluation should emphasize development quality rather than speed and should incentivize local government behaviors through new targets. Regarding the economic reforms, a modern fiscal system should be established by reforming the fiscal and taxation systems. This new system should adjust the fiscal relationship between the central government and local governments and restore the balance of financial powers, among other powers, between both parties. Second, China should reform its real estate tax system to regulate income distribution. A holding link tax should be established to increase the cost of ownership and curb speculation, which could also adjust sources of government revenue. Finally, it is also necessary to improve the transaction link tax, adjust the collection method of the land appreciation tax, and learn from the internationally used capital gains tax to achieve redistribution.

Author Contributions: Conceptualization, J.C.; methodology, J.C.; software, J.C.; validation, J.C.; formal analysis, J.C.; investigation, J.C.; resources, J.C.; data curation, J.Z.; writing-original draft preparation, J.C.; writing—review and editing, H.Z.; visualization, J.Z.; supervision, D.Z.; project administration, D.Z.; funding acquisition, D.Z. All authors have read and agreed to the published version of the manuscript.

Funding: This research was funded by the Program of Research on Theory and Method of Natural Resource Assets Accounting in China, grant number 19JZD013.

Data Availability Statement: The data presented in this study are available on request from the first author.

Conflicts of Interest: The authors declare no conflict of interest.

\section{References}

1. Zhang, P.; Liu, X.; Zhang, X. Capitalization expansion and technological progress of catch-up economy. Econ. Res. J. 2010, 45, 4-20.

2. Zhao, Y. Why land finance is a great institutional innovation. Urban Dev. Stud. 2019, 26, 6-16.

3. Harvey, D. The Limits to Capital; Blackwell: Hoboken, NJ, USA, 1982.

4. De Soto, H. The Mystery of Capital; Bantam Press: London, UK, 2000.

5. $\mathrm{Wu}, \mathrm{F}$. The long shadow of the state: Financializing the Chinese city. Urban Geogr. 2021, 42, 1-22. [CrossRef] 
6. Christophers, B. The state and financialization of public land in the United Kingdom. Antipode 2017, 49, 62-85. [CrossRef]

7. Sharma, S. Down and out in Dhaka: Understanding land financialization and displacement in austerity urbanism. Urban Geogr. 2021, 42, 681-700. [CrossRef]

8. Lin, G.; Yi, F. Urbanization of capital or capitalization on urban land? Land development and local public finance in urbanizing China. Urban Geogr. 2011, 32, 50-79. [CrossRef]

9. Christophers, B. For real: Land as capital and commodity. Trans. Inst. Br. Geogr. 2016, 41, 134-148. [CrossRef]

10. Foster, W.; Anríquez, G.; Melo, O.; Yupanqui, D.; Ortega, J. Geographic disparities in rural land appreciation in a transforming economy: Chile, 1980 to 2007. Land Use Policy 2016, 57, 655-668. [CrossRef]

11. Hirsch, P. Limits to neoliberal authoritarianism in the politics of land capitalisation in Thailand: Beyond the paradox. Can. J. Dev. Stud. 2019, 41, 1-18. [CrossRef]

12. Peterson, G. Land Leasing and Land Sale as an Infrastructure-Financing Option. World Bank Policy Research Working Paper No. 4043. 2006. Available online: https:/ / ssrn.com/abstract=940509 (accessed on 20 August 2021).

13. Whiteside, H. The state's estate: Devaluing and revaluing 'surplus' public land in Canada. Environ. Plan. A 2019, 51, 505-526. [CrossRef]

14. Loehr, D. Capitalization by formalization? Challenging the current paradigm of land reforms. Land Use Policy 2012, 29, 837-845. [CrossRef]

15. Brown-Luthango, M. Capturing land value increment to finance infrastructure investment-Possibilities for South Africa. Urban Forum 2011, 22, 37-52. [CrossRef]

16. Alam, M. Rapid urbanization and changing land values in mega cities: Implications for housing development projects in Dhaka. Bandung 2018, 5, 1-19. [CrossRef]

17. Lapavitsas, C. Financialised capitalism: Crisis and financial expropriation. Hist. Mater. 2009, 17, 114-148. [CrossRef]

18. El-Nagdy, M.; El-borombaly, H.; Khodeir, L. Threats and root causes of using publicly-owned lands as assets for urban infrastructure financing. Alex. Eng. J. 2018, 57, 3907-3919. [CrossRef]

19. Fainstein, S. Financialisation and justice in the city: A commentary. Urban Stud. 2016, 53, 1503-1508. [CrossRef]

20. McMichael, P. The land grab and corporate food regime restructuring. J. Peasant. Stud. 2012, 39, 681-701. [CrossRef]

21. White, B.; Borras, S., Jr.; Hall, R.; Scoones, I.; Wolford, W. The new enclosures: Critical perspectives on corporate land deals. J. Peasant. Stud. 2012, 39, 619-647. [CrossRef]

22. Ding, C. Land policy reform in China: Assessment and prospects. Land Use Policy 2003, 20, 109-120. [CrossRef]

23. Heikkila, E. Three questions regarding urbanization in China. J. Plan. Educ. Res. 2007, 27, 65-81. [CrossRef]

24. Liu, S. Land institutional reform and structural transformation in China: An economic interpretation for China's 40 years development experience. China Land Sci. 2018, 32, 1-10.

25. Liu, Y.; Li, J.; Yang, Y. Strategic adjustment of land use policy under the economic transformation. Land Use Policy 2018, 74, 5-14. [CrossRef]

26. Qi, O.; Bai, Y. Land capitalization and regional disparity: Finance effect and space effect. Econ. Probl. 2016, 38, 22-29. [CrossRef]

27. Zhang, P.; Liu, X. Urbanization, fiscal expansion and economic growth. Econ. Res. J. 2011, 46, 4-20.

28. Huang, D.; Chan, R. On 'Land Finance' in urban China: Theory and practice. Habitat. Int. 2018, 75, 96-104. [CrossRef]

29. Liu, S.; Wang, Z.; Zhang, W.; Xiong, X. The exhaustion of China's 'Land-Driven Development' mode: An analysis based on threshold regression. Manag. World 2020, 36, 80-92. [CrossRef]

30. Zhang, W.; Xu, H. Effects of land urbanization and land finance on carbon emissions: A panel data analysis for Chinese provinces. Land Use Policy 2017, 63, 493-500. [CrossRef]

31. Cheng, J.; Zhu, D.; Zhang, H.; Hu, B. Research on the dynamic inefficiency of China's economy from the perspective of land capitalization. China Land Sci. 2020, 34, 31-38.

32. Feder, G.; Nishio, A. The benefits of land registration and land titling: Economic and social perspectives. Land Use Policy 1999, 15, 25-43. [CrossRef]

33. Deininger, K. Land Policies for Growth and Poverty Reduction; Oxford University Press: Oxford, UK, 2003.

34. Kaika, M.; Ruggiero, L. Land financialization as a "lived” process: The transformation of Milan's Bicocca by Pirelli. Eur. Urban Reg. Stud. 2016, 23, 3-22. [CrossRef]

35. Gunnoe, A. The political economy of institutional land ownership: Non rentier society and the financialization of land. Rural. Sociol. 2014, 79, 478-504. [CrossRef]

36. Borio, C.; Furfine, C.; Lowe, P. Procyclicality of the financial system and financial stability: Issues and policy options. Bis Pap. 2001, 1, 1-57.

37. Rajack, R. Does the Ownership and Management of Public Land Matter to Market Outcomes? Springer: Dordrecht, The Netherlands, 2009.

38. Ely, R.; Moerhouse, E. Elements of Land Economics; The MacMillan Company: New York, USA, 1926.

39. He, C.; Yi, Z.; Huang, Z. Fiscal decentralization, political centralization and land urbanization in China. Urban Geogr. 2016, 37, 436-457. [CrossRef]

40. Fu, Y.; Zhang, Y. Chinese decentralization and fiscal expenditure structure bias: The cost of competition for growth. Manag. World 2007, 23, 4-12. [CrossRef]

41. Li, H.; Zhou, L. Political turnover and economic performance: The incentive role of personnel control in China. J. Public Econ. 2004, 89, 1743-1762. [CrossRef] 
42. Zhou, L. Governing China's local officials: An analysis of promotion tournament model. Econ. Res. J. 2007, 53, 36-50.

43. Zheng, S.; Sun, W.; Wu, J.; Wu, Y. Infrastucture investment, land leasing and real estate price: A unique financing and investment channel for urban development in Chinese cities. Econ. Res. J. 2014, 49, 14-27.

44. Lichtenberg, E.; Ding, C. Assessing farmland protection policy in China. Land Use Policy 2008, 25, 59-68. [CrossRef]

45. Keen, M.; Marchand, M. Fiscal competition and the pattern of public spending. J. Public Econ. 1997, 66, 33-53. [CrossRef]

46. Lu, M.; Zhang, H.; Liang, W. How the bias toward Central/Western land supplies boosts wages in the East. China Soc. Sci. 2015, $36,59-83$.

47. Lu, J. The measurement of the bubble of urban housing market in China. Econ. Res. J. 2010, 45, $28-41$.

48. Nichols, D. Land and economic growth. Am. Econ. Rev. 1970, 60, 332-340.

49. Wang, W.; Rong, Z. Housing boom and firm innovation: Evidence from industrial firm in China. China Econ. Q. 2014, 13, 465-490. [CrossRef]

50. Martin, A.; Ventura, J. Economic growth with bubbles. Am. Econ. Rev. 2012, 102, 3033-3058. [CrossRef]

51. Capozza, D.; Helsley, R. The fundamentals of land prices and urban growth. J. Urban Econ. 1989, 26, 295-306. [CrossRef]

52. Rhee, C. Dynamic inefficiency in an economy with land. Rev. Econ. Stud. 1991, 58, 791-797. [CrossRef]

53. Lin, R.; Zhu, D. A spatial and temporal analysis on land incremental values coupled with land rights in China. Habitat Int. 2014, 44, 168-176. [CrossRef]

54. Chen, S.; Gao, L. The relationship between the central and local governments: Fiscal decentralization measurement and reassessment of the mechanism. Manag. World 2012, 28, 43-59. [CrossRef]

55. Zhou, Y.; Zong, Q.; Chen, X. Yardstick competition among local municipal governments over the education expenditure under decentralized fiscal system. Econ. Res. J. 2013, 48, 127-139.

56. Peck, J.; Tickell, A. Neoliberalising space. Antipode 2002, 34, 380-404. [CrossRef]

57. Feder, G.; Feeny, D. Land tenure and property rights: Theory and implications for development policy. World Bank Econ. Rev. 1991, 5, 135-153. [CrossRef]

58. Chimhowu, A.; Woodhouse, P. Customary vs private property rights? Dynamics and trajectories of vernacular land markets in sub-Saharan Africa. J. Agrar. Chang. 2006, 6, 346-371. [CrossRef]

59. The World Bank. Sharing Growth: Equity and Development in Cambodia_Equity Report 2007; The World Bank: New York, USA, 2007.

60. Christophers, B. The limits to financialization. Dialogues Hum. Geogr. 2015, 5, 183-200. [CrossRef]

61. Haila, A. Urban Land Rent: Singapore as a Property State; Wiley-Blackwell: Oxford, UK, 2016. 